\title{
A longitudinal comparison of capital structure between young for-profit social and commercial enterprises
}

\author{
Ana Cristina O. Siqueira \\ Duquesne University \\ Palumbo Donahue School of Business \\ 600 Forbes Avenue \\ Pittsburgh, PA 15282 \\ United States \\ siqueiraa@duq.edu \\ Nadja Guenster \\ University of Munster \\ School of Business and Economics \\ Finance Center Munster \\ Universitatsstr. 14-16 \\ 48143 Munster \\ Germany \\ nadja.guenster@wiwi.uni-muenster.de \\ Tom Vanacker \\ Ghent University \\ Department of Accounting, Corporate Finance and Taxation \\ Sint-Pietersplein 7, 9000 Gent \\ Belgium \\ TomR.Vanacker@UGent.be \\ Saskia Crucke \\ Ghent University \\ Faculty of Economics and Business Administration \\ Tweekerkenstraat 2 \\ 9000 Ghent \\ Belgium \\ Saskia.Crucke@UGent.be
}

Acknowledgements: We thank the editors, anonymous reviewers, and participants in the JBV Special Issue Symposium at the Ivey Business School and 2017 meeting of the Academy of management in Atlanta, GA for helpful comments on earlier versions of this manuscript.

Keywords: Social entrepreneurship; Capital structure; Imprinting; For-profit social enterprises 


\title{
A longitudinal comparison of capital structure between young for-profit social and commercial enterprises
}

\begin{abstract}
We develop a new perspective on capital structure differences between for-profit social and commercial enterprises by combining imprinting and social entrepreneurship theory. Using a longitudinal matched sample, we find that for-profit social enterprises have $40 \%$ to $13 \%$ lower leverage and up to four times greater leverage stability over time than commercial enterprises. Our results suggest that these differences in capital structure derive from the process of prosocial organizing, which goes beyond the primary focus on financial preferences. Thus, for-profit social enterprises - and similar hybrid organizations, such as B corporations - may require theories adjusted to their context.
\end{abstract}




\section{Executive summary}

There is a growing interest in the financing of social enterprises (Bruton et al., 2015; Fleming and Sorenson, 2016). Nonetheless, the existing entrepreneurial finance literature, with its often explicit focus on profit maximization, has a significant gap in both theorizing and empirical evidence regarding the extent to which capital structures of for-profit social enterprises differ from commercial enterprises. We draw on imprinting theory and the social entrepreneurship literature to develop a new perspective on how capital structure differences emerge and evolve between forprofit social and commercial enterprises.

Taking an imprinting theory perspective (e.g., Boeker, 1989; Stinchcombe, 1965), entrepreneurs are expected to shape capital structures at founding and initial capital structures will have a lasting influence on future capital structures. Entrepreneurs in for-profit social enterprises want to create value for society and aim to find sustainable solutions to social and environmental problems (Mair et al., 2012; Santos, 2012). Because social goals often require longer term investments (Bacq and Lumpkin, 2014), for-profit social entrepreneurs also tend to have a longer term orientation than commercial entrepreneurs. Consequently, for-profit social entrepreneurs may prefer to avoid situations where they have to subordinate their (longer term) social goals to the (shorter term) financial necessity of having to make strictly-timed debt payments. Therefore, our first hypothesis states that over time capital structures of for-profit social enterprises will include less debt financing than commercial enterprises.

Social entrepreneurs, with compassion and motivation to create social value (Miller et al., 2012), are unlikely to compromise their social goals, when more debt becomes optimal from a purely financial perspective, thereby making their capital structures more persistent. Furthermore, attention is a scarce resource, particularly for for-profit social entrepreneurs, who are managing more complex, hybrid organizations (Stevens et al., 2015b). Consequently, for-profit social 
entrepreneurs may also spend less attention to analyzing and adjusting their capital structures than commercial entrepreneurs. Therefore, our second hypothesis states that the influence of initial leverage ratios on future leverage will remain stronger over time among for-profit social enterprises than commercial enterprises.

To test these hypotheses, we use a quasi-experimental approach. Specifically, we construct a longitudinal dataset from 2005 to 2015 comprising 120 young for-profit social and 120 commercial enterprises, matched by industry, firm age, and firm size. From the Flemish government (a regional government in Belgium), we obtained the population of Flemish firms that carry the "Social Purpose Company" (SPC) legal label. SPCs are similar to Certified B Corporations (B Corps) with regard to the requirements of carrying a for-profit legal form, pursuing both for-profit and social goals, and having a formal commitment to assessing and reporting social impact. The for-profit social enterprises and matched commercial enterprises in our sample are subject to the same accounting standards and report detailed yearly financial accounts data to the Belgian National Bank in a predefined format. Using this unique dataset, we find support for our hypotheses. Specifically, capital structures tend to have lower debt levels and are significantly more stable over time within for-profit social enterprises compared to commercial enterprises.

Our study contributes to the entrepreneurial finance literature by providing a first-time longitudinal glimpse in how capital structures of for-profit-social and commercial enterprises differ over time. Capital structure and the use of debt plays a crucial role in firms and can significantly influence firm survival and growth (Åstebro and Bernhardt, 2003; Robb and Robinson, 2014). Our findings suggest that important differences in capital structure derive from imprints of prosocial organizing of capital structure - an element that has been largely overlooked in traditional capital structure theories. Thus, standard capital structure theories need important adjustment for the context of for-profit social enterprises. In this way, our study also contributes to the social 
entrepreneurship literature by emphasizing substantive differences between for-profit social and commercial enterprises (Santos, 2012) and how these differences generate distinct expectations of entrepreneurial behaviors including capital structure decisions. Finally, this study helps inform stakeholders and policy makers about the challenges and consequences of capital structure decisions while pursuing both economic and social goals, as well as the relevance of financing sources for new for-profit social enterprises that fit with their hybrid goals.

\section{Introduction}

Scholars have shown growing interest in the unique challenges of financing social enterprises (Bruton et al., 2015; Fleming and Sorenson, 2016). The theme of financing social enterprises is examined from various angles including crowdfunding (Allison et al., 2015; Dushnitsky et al., 2016), investor decision making (Moss et al., 2015; Thébaud, 2015), and new organizational and legal forms (Haymore, 2011; Reiser, 2010). Moreover, it is often argued that social entrepreneurs tend to be cautious about adding outside financing sources to their financial structure (Sunley and Pinch, 2012) and that they experience particular difficulties in identifying and accessing funding sources that are interested in creating social value at the expense of financial returns (Calic and Mosakowski, 2016; Certo and Miller, 2008; Doherty et al., 2014).

The existing entrepreneurial finance literature, however, has a significant gap in both theorizing and empirical evidence regarding the extent to which capital structures of for-profit social enterprises emerge differently and how these differences evolve in their entrepreneurial journeys over time compared to commercial enterprises (McMullen and Dimov, 2013). Theoretically, standard capital structure perspectives assume profit maximization as the entrepreneur's sole objective (Sapienza et al., 2003) and they largely ignore the role of differences in company long-term orientation (Bacq and Lumpkin, 2014), which are problematic when 
comparing social and commercial entrepreneurs. Empirically, studies of capital structure have almost exclusively examined young or small commercial enterprises (Cassar, 2004; Cosh et al., 2009).

In this study, we examine the following research question: How does capital structure differ between young for-profit social and commercial enterprises over time? We develop a new perspective based on imprinting theory and the social entrepreneurship literature. Specifically, we hypothesize that there will be two types of differences in capital structures between for-profit-social and commercial enterprises. First, over time capital structures of for-profit social enterprises will include less debt than capital structures of commercial enterprises. Second, over time the relationship between initial capital structure and future capital structure will remain stronger for for-profit social enterprises relative to commercial enterprises.

We empirically test these hypotheses using a longitudinal matched sample of young forprofit social enterprises and commercial enterprises (i.e., pure for-profit businesses in various industries). The for-profit social enterprises in our sample state their social aim in their statutes, explicitly integrate social objectives, publish a special annual report assessing their performance, and carry the legal label "Social Purpose Company" (SPC) in Belgium (Stevens et al., 2015a; Szymańska et al., 2015). SPCs are considered a progenitor to B corps and Benefit Corporations as they were introduced into the Belgian Company Code in 1995 (Defourny and Nyssens, 2008). Our findings support our hypotheses.

Our findings are relevant to the emerging body of work on prosocial hybrid organizations including B Corps (Gehman and Grimes, 2016) because the for-profit social enterprises in our sample share several similarities with other for-profit hybrid categories (Rawhouser et al., 2015) and differences compared to commercial enterprises. Specifically, our study is one of the first to examine capital structure differences between legally acknowledged for-profit social enterprise 
forms and commercial enterprises. Our results show important differences in capital structure, which given our matched sample, most likely derive from imprints of prosocial organizing of capital structure that goes beyond financial preferences. Because prosocial organizing of capital structure is largely ignored in existing capital structure theories that take a profit maximizing paradigm, our findings highlight how for-profit social enterprises (and similar hybrid organizations) require theories adjusted to their specific context (e.g., Santos, 2012; Wry and York, 2017).

\section{SPCs and social enterprise categories across countries}

Governments across the globe have developed specific innovative legal frameworks for social enterprises (Defourny and Nyssens, 2008). These new legal frameworks were mainly introduced as an answer to a changing reality and as a way to encourage social entrepreneurship. First, the number of new social enterprises has substantially increased in many regions of the world (Kerlin, 2013), while many existing non-profit organizations evolved to some form of social entrepreneurship (Cooney, 2011). By consequence, governments introduced new legal frameworks because of the increased legislative needs to capture this changing reality. Second, governments and public sector organizations also increasingly considered social entrepreneurship as an effective way to tackle a variety of unsolved social problems. A sound legal framework can sustain the development of the social enterprise sector (Nicholls, 2010).

The SPC legal label, tailored to for-profit social enterprises, was introduced into the Belgian Company Code in 1995. The SPC label in Belgium is similar to other legal forms for social enterprise categories in other countries, such as the Social Co-Operative in Italy in 1991 and related legal forms of the co-operative type in Portugal in 1997, Spain in 1999, Greece in 1999, and France in 2002 (Defourny and Nyssens, 2008). New legislation in the United Kingdom introduced the 
Community Interest Company in 2005 to stress the business character of social enterprises (Nicholls, 2010). Compared to these new legal forms, however, the SPC in Belgium is, strictly speaking, not a new legal form, but a legal social "label" on top of a for-profit legal form.

In the United States, new legal forms were established in different states of which the most prominent has been the Benefit Corporation introduced in 2010 (André, 2012; Ebrahim et al., 2014; Rawhouser et al., 2015). Unlike the SPC label, the Benefit Corporation legal form requires companies to conduct an assessment of their overall social and environmental performance against a third-party standard (Benefit Corporation, 2017; Fosfuri et al., 2016). However, with regard to the requirements of carrying a for-profit legal status, formally pursuing a public benefit in addition to profit, and publishing an annual benefit report (Fosfuri et al., 2016; Hiller, 2013), the conditions for adopting the SPC legal label are very similar to those for the Benefit Corporation legal form.

Over a decade after the introduction of the SPC label in Belgium, another important event was the founding of the nonprofit organization B Lab in the United States, which initiated the work of certifying companies with different types of for-profit legal forms in various countries as B Corps by assessing their social impact (B Corporation, 2017). While audit by an independent organization is not a condition to become a SPC in Belgium, SPCs in Belgium can also become a B Corp. ${ }^{1}$ Comparing SPCs to B Corps, SPCs do not carry a specific "certification" like B Corps, but with regard to the requirements of carrying a for-profit legal form, pursuing social goals in addition to profit, and having a formal commitment to assessing and reporting social impact, SPCs are very similar to B Corps.

The Benefit Corporation legal status in the United States is separate from the B Corp Certification, which is valid in multiple countries. Benefit Corporations are required to conduct

\footnotetext{
${ }^{1}$ One of the SPCs in our sample is a B Corp in Belgium.
} 
audits of social impact by any third party, one alternative of which is B Lab's B Corporation Certification. In contrast, companies of different for-profit legal forms must be certified by the B Lab in order to become a B Corp (Rawhouser et al., 2015). Even if they do not have a Benefit Corporation status, for-profit companies can obtain a B Corp Certification. In sum, the SPCs in this study are similar to several for-profit hybrid categories like Benefit Corporations and B Corps.

\section{Theory and hypotheses}

\subsection{Problematizing traditional capital structure theories}

The static trade-off theory and pecking order theory are two of the most influential theoretical perspectives in finance research on firm capital structure (Frank and Goyal, 2009). While these perspectives were originally developed in the context of established, large, and public firms, they have been extended and successfully applied to new, small, and private firms (Cassar, 2004; Cosh et al., 2009; Heyman et al., 2008).

In the static trade-off theory, entrepreneurs trade-off the benefits and costs of debt financing. Debt has an important benefit relative to equity in most countries' corporate tax system: interest payments are tax-deductible but dividends and retained earnings are not (or less so). Therefore, debt yields a benefit in that it shields earnings from taxes (Modigliani and Miller, 1963). However, the use of debt may also cause financial distress costs (Kraus and Litzenberger, 1973). Debt entails fixed payments (i.e., interest and principal repayment) and (the risk of) late or no payment causes direct and indirect financial distress costs. Direct costs include the legal fees and expenses incurred in bankruptcy proceedings. Indirect costs refer, for example, to the reluctance of customers and suppliers to do business with a firm that has a higher bankruptcy risk (Altman, 1984; Titman, 1984; 
Opler and Titman, 1994). Even if the firm eventually does not go bankrupt, the indirect costs of financial distress can be very high (Opler and Titman, 1994). ${ }^{2}$

In the pecking order theory, the information asymmetry between entrepreneurs and investors is of first-order importance (Myers, 1984; Myers and Majluf, 1984). Entrepreneurs typically have more information about firm quality than external investors, which leads to adverse selection problems. External investors therefore require a "lemons" premium (Akerlof, 1970) and with rising information asymmetry financing becomes more costly. Because internal equity is not subject to information asymmetry problems, entrepreneurs prefer to use internal equity (i.e., retained earnings) to finance new investments. When internal equity is insufficient, they turn to debt, which is less information-sensitive to the true quality of firms than external equity. Finally, as a last resort, they turn to external equity. ${ }^{3}$

Both traditional capital structure theories conceptualize entrepreneurs as financial value maximizers, where financial value maximization is the firm's sole objective (Sapienza et al., 2003). This conceptualization results in time-varying capital structures because entrepreneurs instantaneously (or with some delay due to market imperfections such as transaction costs) change capital structures as the fundamental drivers of capital structure change. In the trade-off theory, entrepreneurs optimize capital structure so that the marginal benefit of an additional unit of debt equals its marginal cost (Frank and Goyal, 2009). Capital structure is expected to change over time because the benefits and costs of debt vary as firms age. In the pecking order theory, firms have no optimal capital structure but capital structures reflect firms' cumulative past requirements for

\footnotetext{
${ }^{2}$ Debt has also been associated with different agency benefits and costs. For instance, a benefit of debt is that it reduces agency problems in firms with large amounts of cash (Jensen, 1986). But too much debt might also cause agency costs, which could be consider as a third type of financial distress costs. Specifically, highly levered firms with significant growth opportunities may face an underinvestment problem where shareholders (entrepreneurs) may forego valuecreating investments (Myers, 1977).

${ }^{3}$ Entrepreneurial finance scholars have further suggested that a pecking order might result not only from informational asymmetry but also from entrepreneurs' willingness to retain control over their ventures (Sapienza et al., 2003).
} 
external finance (Brav, 2009; Myers, 1984; Shyam-Sunder and Myers, 1999). Because firms' financing deficits (or surpluses) change over time, these changes also create time-varying capital structures.

The conceptualization of entrepreneurs as continuously maximizing financial value and its implications for capital structure are problematic for at least two reasons. First, over the last decades, an increasing number of organizations operate at the intersection between commercial and social sectors (Santos, 2012). Unlike entrepreneurs in the traditional capital structure theories, who maximize solely firm financial value, for-profit social entrepreneurs gain utility from value creation for society (Baron, 2007; Miller et al., 2012) and conduct a pro-social cost-benefit analysis (Miller et al., 2012). Moreover, social goals also often require longer-term investments and, therefore, forprofit social enterprises have a longer-term orientation than commercial enterprises (Austin et al., 2006; Bacq and Lumpkin, 2014). ${ }^{4}$

Second, the traditional capital structure perspectives have been challenged by empirical evidence of the long-run stability of capital structure (Lemmon et al., 2008). In an entrepreneurial context, Hanssens et al. (2016) show that debt policies at founding are strongly related to future debt policies for up to 15 years after founding. They suggest that the persistence in capital structure could be explained by imprinting theory (Stinchcombe, 1965; Boeker, 1989). In sensitive periods, such as organizations' founding, entrepreneurs implement certain policies, which persist over time (Marquis and Tilcsik, 2013). Again, this evidence suggests that the conceptualization of entrepreneurs as pure financial value maximizers, who continuously optimize their firms' capital

\footnotetext{
${ }^{4}$ For example, Work Integration Social Enterprises are a common type of for-profit social enterprises (Battilana et al., 2015). These enterprises employ individuals who face barriers to employment such as disabilities and focus on reintegrating long term unemployed into the work force. While these are important long term social objectives, employing these people may not be cost efficient and may not maximize short-term financial performance, which is exactly one reason that they face barriers to employment in the traditional labor market (Crucke and Knockaert, 2016). Not only social objectives, but also environmental problems, for example climate change, can only be addressed with a long-term perspective (Slawinski and Bansal, 2012, 2015).
} 
structures, is not realistic. To date, however, we lack a theoretical understanding and empirical evidence on how capital structures might evolve differently among for-profit social enterprises and commercial enterprises.

\subsection{Capital structure in for-profit social enterprises versus commercial enterprises}

By drawing on the imprinting theory and social entrepreneurship literature, we develop a new perspective to understand capital structure differences between for-profit social and commercial enterprises. We claim that capital structures of for-profit social enterprises and matched commercial entrepreneurs will exhibit two types of differences: (1) a "level effect" (where over time capital structures of for-profit social enterprises will include less debt than capital structures of commercial enterprises) and (2) a "sensitivity effect" (where over time the relationship between initial capital structure and future capital structure will remain stronger for for-profit social enterprises relative to commercial enterprises). We now develop these claims in more detail.

\subsubsection{Level effect}

The foundations of organizational imprinting theory date back to Stinchcombe (1965: 153) who has highlighted that "organizational forms and types have a history, and this history determines some aspects of the present structure of organizations of that type." More broadly, imprinting is "a process whereby, during a brief period of susceptibility, a focal entity develops characteristics that reflect prominent features of the environment, and these characteristics continue to persist despite significant environmental changes in subsequent periods" (Marquis and Tilcsik, 2013: 199). Research has also focused on the role of entrepreneurs, who can leave long-lasting "stamps" on their firms as well (e.g., Baron et al., 1999a, 1999b; Beckman and Burton, 2008; Eisenhardt and Schoonhoven, 1990). More specifically, when entrepreneurs shape initial firm characteristics, 
policies, or practices-including initial capital structures-they become imprinted and thus influence firms' future characteristics, policies, or practices long after founding (Boeker, 1989).

We argue that the capital structure of for-profit social enterprises will systematically include less debt than the capital structures of matched commercial enterprises. A first important reason for our claim is that entrepreneurs in for-profit social enterprises may demand less debt than entrepreneurs in matched commercial enterprises. To understand why this would be the case, it is important to recognize a key structural difference between debt and equity financing. Specifically, debt has a fixed payment schedule for interest payments and the repayment of principal. If firms do not (timely) pay their debt obligations, or stakeholders believe they might not be able to do so, firms face direct and indirect financial distress costs (Opler and Titman, 1994). In contrast, equity is a much more flexible financing instrument. There is no legal obligation to pay dividends. Firms only need to declare dividends, if they are willing and able to pay them.

This structural difference between debt and equity financing has important implications, particularly for for-profit social enterprises. Specifically, when future earnings get delayed unexpectedly, debt brings a twin disadvantage for for-profit social enterprises. Debt increases the direct and indirect bankruptcy costs thereby hampering firm financial performance as would be the case for commercial enterprises as well. However, unique to for-profit social enterprises, debt payments might further force them to subordinate their longer-term nonfinancial goals (e.g., social and environmental goals) to financial necessities. Because firms are legally obliged to service the fixed debt payments to avoid financial distress, commercial goals need to be prioritized to ensure the firm's survival. This forced prioritization is likely going to be at odds with the social goals that often drive for-profit social entrepreneurs (Bacq and Lumpkin, 2014; Germak and Robinson, 2014; Miller et al., 2012). For-profit social entrepreneurs, who employ a pro-social cost-benefit analysis 
(Miller et al., 2012), may hence prefer a capital structure with less debt that preserves them more flexibility to achieve their non-financial goals.

A second reason why the capital structure of for-profit social enterprises might include less debt than the capital structure of matched commercial enterprises is that the availability of debt financing in their environment might differ. More specifically, the hybridity that characterizes forprofit social enterprises makes them more complex and complicates performance measurement relative to commercial enterprises (Austin et al., 2006). This increased complexity might limit the willingness of traditional bankers to provide debt finance to for-profit social enterprises. ${ }^{5}$ Moreover, bankers have guidelines to follow and contrary to equity investors they are unlikely (or less likely) to include pro-social aspects in their decision on granting a loan (or not). Indeed, empirical evidence suggests that many banks do not value (or underestimate) the social and longterm economic benefits that may accrue from social enterprise activity (e.g., Sunley and Pinch, 2012). Providers of equity finance for for-profit social enterprises, however, often share the entrepreneur's social objectives (Nicholls, 2010); they do not punish poor financial performance of for-profit social enterprises the same way as they do for commercial enterprises (Austin et al., 2006).

In sum, relative to entrepreneurs in commercial enterprises, entrepreneurs in for-profit social enterprises are less likely to demand debt because the characteristics of debt financing (i.e., strictlytimed, fixed debt payments) may hamper their ability to pursue their social goals in the future.

\footnotetext{
${ }^{5}$ An alternative explanation for why for-profit social enterprises might have less access to debt relative to commercial enterprises is that the former on average generate lower profits and have fewer tangible assets (Fedele and Miniaci, 2010; Foster and Bradach, 2005). However, this alternative explanation cannot drive our hypothesis or explain our findings because in all our empirical models we control for the traditional factors (e.g., profitability and tangibility of assets) that influence the availability of debt financing for for-profit social enterprises and commercial enterprises (Fedele and Miniaci, 2010; Szymańska et al., 2015).
} 
Moreover, debt financing may be less available for for-profit social enterprises than commercial enterprises given the greater complexity of the former. Thus,

Hypothesis 1 (Level effect): Over time, the capital structures of for-profit social enterprises will include less debt than the capital structures of matched commercial enterprises.

\subsubsection{Sensitivity effect}

In an imprinting theory perspective, entrepreneurs adopt capital structures during sensitive periods such as firm founding and these capital structures subsequently persist (Hanssens et al., 2016). However, imprints do not always persist; there is indeed some evidence that imprints can amplify or decay over time (Kwon and Ruef, 2017; Simsek et al., 2015). In our context, this entails that the relationship between initial capital structures and future capital structures can remain strong, strengthen or weaken, respectively. We expect that the relationship between initial capital structures and future capital structures will remain particularly strong over time for for-profit social enterprises relative to commercial enterprises.

First, unlike entrepreneurs in commercial enterprises, entrepreneurs in for-profit social enterprises are also driven by compassion to create social value, which is a "longer-term emotion" that can have a particularly enduring effect on channeling entrepreneurs' interests and actions (Miller et al., 2012: 622). For example, when for-profit social entrepreneurs use little or no debt financing at founding to ensure that they do not need to compromise their social goals at a later stage, their initial choice is driven by a pro-social ideology. As Stinchcombe (1965: 169) points out "...the working out of ideologies may tend to preserve the structure." For-profit social entrepreneurs are unlikely to compromise their social goals and change their initial financing decisions that were incorporating these goals. Thus, even when more debt becomes optimal from 
a purely financial perspective or more debt becomes available in their environment as firms develop a track record or establish relationships with bankers (e.g., Berger and Udell, 1998), initial capital structure might still preserve.

Relatedly, because other stakeholders in for-profit social enterprises, such as employees and shareholders, often share the entrepreneurs' social objectives (Benz, 2005; Austin et al., 2006), firms' longer-term social interests may also bring a stronger consensus around the initial capital structure. Greater consensus around decisions at founding makes these decisions less open to subsequent questioning or redirection (Boeker, 1989). Thus, financing decisions at founding might lead to particularly powerful imprints in for-profit social enterprises, thereby explaining why the former will have a more persistent capital structure over time than similar commercial enterprises.

Second, due to limited information processing capacity, entrepreneurs' attention to various organizational goals and the hundreds of interrelated activities within firms is selective (Bromiley, 2005; Ocasio, 1997). Stevens and colleagues (2015b) highlight that for-profit social entrepreneurs face the particular challenge of allocating attention to their firms' social and financial goals. Thus, for-profit social entrepreneurs realistically have less attention to spend on each goal and to specific activities such as the adjustment of capital structure relative to commercial entrepreneurs. This more limited attention by for-profit social entrepreneurs is expected to lead to more persistent capital structures that do not necessarily maximize financial value. But, as for-profit social entrepreneurs also want to create value for society and not only capture maximum financial value for themselves or their enterprises (Santos, 2012), the limited attention to the capital structure of their firms is not necessarily suboptimal from their personal perspective. Consequently, as long as the capital structure of for-profit social enterprises is not viewed as "problematic" for firms' attainment of social goals, for profit-social entrepreneurs might focus less of their attention on optimizing their firms' capital structures. For commercial entrepreneurs, however, initial capital 
structures may be more quickly viewed as "problematic" when it no longer supports the primary objective of maximizing financial value.

In sum, we expect that entrepreneurs in for-profit social enterprises are less likely to change their initial capital structure-because it incorporates their and other stakeholders' enduring social goals-relative to entrepreneurs in commercial enterprises. For-profit entrepreneurs may also pay more limited attention to financing activities, which further increases capital structure persistence. Consequently, the capital structures that have been imprinted at the sensitive period of firm founding are likely to have more persistent effects for-profit social enterprises than commercial enterprises. Thus,

Hypothesis 2 (Sensitivity effect): The influence of initial leverage ratios on future leverage will remain stronger over time among for-profit social enterprises than among matched commercial enterprises.

\section{Methods}

\subsection{Sample and data sources}

To test our hypotheses, we use a quasi-experimental approach (Shadish et al., 2002; Van de Ven, 2007). Specifically, we construct a matched sample of for-profit social enterprises and commercial enterprises based on four characteristics, namely, geographical region, industry, firm age, and firm size (Lerner, 1999; Megginson and Weiss, 1991; Puri and Zarutskie, 2012). This approach allows us to make claims about differences between for-profit social enterprises and commercial enterprises that are (almost) identical on specific observable characteristics. ${ }^{6}$ By doing

${ }^{6}$ As we detail below, we additionally control for other potentially confounding factors that we did not use to match for-profit social enterprises and commercial enterprises. These confounding factors include our controls for the 
so, it improves our ability to draw causal inferences from real-life data, because the matching process "amounts to a search for a data set that might have resulted from a randomized experiment but is hidden in an observational data set. When matching can reveal this "hidden experiment," many of the problems of observational data analysis vanish" (King and Nielsen, 2016: 2). Below, we first describe the construction of our sample of for-profit social enterprises and then detail our approach to construct a matched sample of commercial enterprises.

Sampling issues are considered challenging when studying social enterprises (Short et al., 2009). Researchers can use a respondent-driven sample of social enterprises or use a purposive sample of social enterprises, thereby starting from a population of firms that have dominant social goals (Stevens et al., 2015a). We followed the latter approach because we examine "Social Purpose Companies" (SPCs) ("Vennootschappen met Sociaal Oogmerk") in Flanders, a region in Belgium. Our focus on SPCs in the Flemish context facilitated our investigation in several ways. First, we minimize unobserved heterogeneity among firms resulting from variance in governmental policies. This issue is important because Belgium has a federal structure where social economic policies are largely organized at the regional level. Flanders is the largest of three regions in terms of economic activity and population in Belgium. Second, in Belgium, all firms with limited liability of shareholders - irrespective of their age or size - are required by law to report yearly financial statement data in a predefined format to the National Bank of Belgium. These financial statement data are detailed and comprise over 25 pages of data for each firm.

From the Flemish government, we obtained the population of Flemish SPCs. We link the governmental list of SPCs with the Bel-first database, which is relatively straightforward as both include a unique firm identifier (i.e., the firm's Value Added Tax code). The Bel-first database

traditional capital structure variables (e.g., profitability and tangibility) and other variables specific to our context (e.g., subsidy finance). 
comprises annual balance sheet, income statement and social balance sheet-reporting the number of employees and composition of the workforce — data (e.g., Vanacker and Forbes, 2016). The Belfirst database is compiled by Bureau van Dijk (BvD)—one of Europe's leading electronic publishers of business information. When the financial statements are filed with the National Bank of Belgium, they are processed and checked and subsequently made available to the public. BvD collects these data to compile the Bel-first database. We obtained detailed data for 192 for-profit social enterprises between 2005 and 2015. We select young for-profit social enterprises, defined as firms 12 years old or younger (Hannan et al., 1996; Hoang and Antoncic, 2003). Moreover, for the purpose of our study, we need for-profit social enterprises with at least three data points. As such, we obtain a data set comprising 610 firm-year observations representing 121 for-profit social enterprises.

For each Flemish for-profit social enterprise, we search in the Bel-first database-comprising data on over 450,000 Flemish firms - for a Flemish commercial enterprise, with a for-profit judicial form, active in the same industry (i.e., NACE Rev. 2 section, similar to the US SIC industry coding system), founded in the same year and with similar size (i.e., total assets) as the for-profit social enterprise in the first year it is recorded in our dataset. ${ }^{7} \mathrm{We}$ fail to find a good match for only one for-profit social enterprise. ${ }^{8}$ We then collect longitudinal data up to 2015 for the matched sample of commercial enterprises. These steps result in a final dataset of 1,276 firm year observations

\footnotetext{
7 We acknowledge that propensity score matching represents an alternative matching approach. However, this "enormously popular method of preprocessing data for causal inference, often accomplishes the opposite of its intended goal - increasing imbalance, inefficiency, model dependence, and bias" (King and Nielsen, 2016: 1). While there are alternative approaches, our approach is consistent with recent influential work (e.g., Puri and Zarutskie, 2012).

${ }^{8}$ In general, we could find for each for-profit social enterprise a commercial enterprise with an (almost) identical size. However, in only one case, we could not match a for-profit social enterprise with a commercial enterprise on firm size. For this case, we matched the for-profit social enterprise with a commercial enterprise founded one year earlier (which actually refers to a difference in firm age of only a few months). By doing so, we were able to find a matched commercial enterprise of equal size relative to the for-profit social enterprise.
} 
representing 240 firms, of which 607 firm-year observations relate to 120 for-profit social enterprises and 669 firm-year observations relate to 120 matched commercial enterprises.

Table 1 summarizes key descriptive data on the matching criteria and demonstrates that there are no significant differences in industry distribution, age, and size between the Flemish for-profit social enterprises (SEs) and matched Flemish commercial enterprises (CEs) in the first year they are recorded in our longitudinal data set (i.e., the year of matching). In all Tables and Figures, we use the abbreviation SEs for for-profit social enterprises and CEs for the matched commercial enterprises.

\section{--- Insert Table 1 about here ---}

Table 1 shows that the for-profit social enterprises in our sample belong to a wide range of industries. What often distinguishes the for-profit social enterprises in our sample from their commercial counterparts is the focus on the work integration of disadvantaged people in society. The social aim of such Work Integration Social Enterprises (WISE) is the social and professional reintegration of disadvantaged people, such as disabled people and people with social or psychological problems. WISEs offer a job to these people while producing goods and services for the commercial market. As such, they have to compete with commercial enterprises, while they also have to invest in social support and job training to make the reintegration of their workers in the labor market possible (Battilana et al., 2015). Some activities of the WISEs in our sample are gardening, cleaning, recycling, packaging, printing, and mailing services. However, our sample of for-profit social enterprises is not limited to WISEs. Some for-profit social enterprises offer services to specific vulnerable groups. An example is an organization offering childcare to children with special needs, for instance, children with cancer. In our sample, there are also several organizations offering support to people, who want to start their own business. Because of their social aim, they focus on people, who need additional support, such as low-skilled people or 
refugees. Another group of for-profit social enterprises in our sample are firms, which want to solve ecological problems. Examples of such for-profit social enterprises are architects or construction firms, using solely eco-friendly methods and materials.

\subsection{Measures}

The dependent variable is Leverage, defined as the book value of total financial debt (including short term and long term financial debt) on total assets. Because all for-profit social enterprise and matched commercial enterprise in our sample are private firms, we use book values, as is standard in studies on capital structure in private firms (Cassar, 2004; Degryse et al., 2012; Heyman et al., 2008; Michaelas et al., 1999; Sogorb-Mira, 2005). Importantly, the for-profit social enterprises and commercial enterprises that we examine in this study are not subject to different accounting standards. Thus, all variables are calculated using the same set of accounting standards, which makes a direct comparison between both types of enterprises more straightforward.

The independent variables include For-profit social enterprise (SE), which is defined as a dummy variable equal to 1 when a firm is a for-profit social enterprise and zero if a firm is a matched commercial enterprise (CE). This variable, related to hypothesis 1, captures the average difference in the level of leverage between for-profit social enterprise and commercial enterprise over the time frame of our study. To examine the persistence of leverage, we also construct a variable Initial leverage, which measures leverage in the first year a firm enters into the sample (Hanssens et al., 2016; Lemmon et al., 2008). ${ }^{9}$ This variable, related to hypothesis 2, captures the

\footnotetext{
${ }^{9}$ Generally, the initial year a firm enters into our dataset is the founding year of the firm. However, there are a few exceptions because we start to collect data from 2005. Thus, over the time frame of our study (i.e., 2005-2015), some firms were founded before 2005. For example, if a firm is founded in 2003, initial leverage is in 2005 given that we only have data from 2005. Once firms enter our sample, there are no cases in which a firm changes from commercial enterprise into a for-profit social enterprise, so all firms remain with their original legal form or legal label.
} 
average relationship between initial leverage and future leverage ratios over the time frame of our study.

Our study further includes Time as a moderator variable, which is a count variable that captures the number of years a firm is in our sample. We interact For-profit social enterprise $x$ Time to examine if differences in the level of leverage between for-profit social enterprise and commercial enterprise change over time (related to hypothesis 1). We further interact Initial leverage $x$ Time to examine if the relationship between initial leverage and future leverage changes over time (related to hypothesis 2).

The control variables include the "traditional" capital structure determinants. Previous research has identified four major determinants of a firm's leverage ratio (e.g., Brav, 2009; Heyman et al., 2008; Rajan and Zingales, 1995): firm profitability, growth opportunities, tangibility, and firm size. First, Profitability is defined as earnings before interest and taxes (EBIT) on total assets (Hanssens et al., 2016; Michaelas et al., 1999; Sogorb-Mira, 2005). More profitable firms generally use less debt financing, in line with pecking order theory predictions (Degryse et al., 2012). Second, Tangibility is defined as property, plant, and equipment on total assets. This variable captures the proportion of assets that are particularly suitable as collateralizable assets (Degryse et al., 2012; Heyman et al., 2008). Firms with more collateralizable assets generally use more debt financing, in line with pecking order and static trade-off theory (Degryse et al., 2012). Importantly, by incorporating profitability and collateral, we also control for the creditworthiness of firms (a key determinant of the availability of bank debt) because lenders generally prefer to finance firms with sufficient internal funds and collateral (Berger and Udell, 1998). Third, Growth is defined as growth in total assets (i.e., total assets $_{t} /$ total $_{\text {assets }}$ t-1 $_{1}$ ). Current growth is often employed as a proxy for growth opportunities (Heyman et al., 2008; Scherr and Hulburt, 2001). We focus on growth in total assets because small firms are not obliged to report sales figures in Belgium. Firms 
with higher growth have larger financing needs and thus generally use more debt financing, in line with the pecking order theory (Degryse et al., 2012). Fourth, Size is defined as the natural logarithm of total assets (Degryse et al., 2012; Heyman et al., 2008; Sogorb-Mira, 2005). Larger firms are characterized by lower bankruptcy risks and lower informational asymmetry and thus may have easier access to (cheaper) bank debt. Thus, traditional capital structure theories suggest that larger firms will use more debt (Degryse et al., 2012).

More specific to our context, a potentially important difference between for-profit social enterprises and commercial enterprises is that the former are likely to receive more government incentives and support than the latter. This difference in government support and more particularly the availability of alternative sources of funding (e.g., subsidies) may potentially explain why forprofit-social enterprises exhibit different financing structures than commercial enterprises. Thus, it is important to control for Subsidies defined as subsidies (e.g., operating subsidies, interest subsidies and capital subsidies) on total assets.

We also include control variables that relate to the composition of a firm's workforce, where the workforce includes management staff, employees, and workers. Note that in our sample the "workforce" of the median "enterprise" is often limited to one individual. Hence, the terms "enterprise" and "workforce" should be interpreted in a broad sense and are likely to include only an entrepreneur. Prior research indicates that male entrepreneurs generally use more outside sources of financing relative to female entrepreneurs and that more highly educated entrepreneurs use more startup capital (Coleman and Robb, 2009; Robb et al., 2009). Thus, we include the proportion of male employees to total employees (Prop male) and the proportion of employees with a university education or equivalent higher education to total employees (Prop highly educated). 
The for-profit social enterprises and commercial enterprises in our sample operate in different industries. Because industry effects are important determinants of firms' debt ratios (Degryse et al., 2012), we include industry fixed effects. We further include year fixed effects to control for any economic event or trend in our data.

\subsection{Econometric approach}

To avoid issues of reverse causality, our dependent variable is measured at time $t$, while our independent and control variables are measured at time t-1 (with the exception of initial leverage, which is by definition measured at $\mathrm{t}=0$ ). We further winsorize variables that are prone to outliers so that extreme values are converted to a variable's 2.5 th or 97.5 th percentiles (e.g., Miller and Breton-Miller, 2011). We estimate our empirical models using Generalized Estimating Equations (GEEs), which accommodate the analysis of panel data with repeated, within-subject measures (Ballinger, 2004). GEEs for modeling longitudinal data account for remaining unobserved heterogeneity across firms and further account for the lack of independence across observations for the same firm (e.g., Katila and Ahuja, 2002). An advantage of GEEs is that they do not require distributional assumptions (Fitzmaurice et al., 2012). For all GEEs, we use an exchangeable correlation structure and report robust standard errors. ${ }^{10}$

\section{Results}

\subsection{Descriptive statistics}

Table 2 provides descriptive statistics and correlations between all variables used in the multivariate analysis, except for industry and year dummies, for the for-profit social enterprise

\footnotetext{
${ }^{10}$ We also estimated pooled panel Tobit regressions with heteroskedasticity consistent standard errors, corrected for correlation across observations of a given firm. Our results remain qualitatively similar.
} 
sample (Panel A) and commercial enterprise sample (Panel B). Mean leverage is markedly lower for for-profit social enterprises $(0.15)$ relative to commercial enterprises $(0.23)$. Mean profitability is negative for for-profit social enterprises $(-2 \%)$, while it is positive for commercial enterprises (9\%). For-profit social enterprises hold on average fewer tangible assets (25\% versus $37 \%)$ and exhibit higher average growth rates (17\% versus $10 \%)$ than commercial enterprises. Over the time frame of our study, the average for-profit social enterprise is larger than the average commercial enterprise (note that there was no significant difference in firm size between for-profit social enterprises and commercial enterprises at the time of matching). The for-profit social enterprises obtained more subsidies (3\%) than the commercial enterprises, for which subsidies are negligible. The correlation between profitability (tangibility) and leverage is negative (positive) in both samples. The correlation between initial leverage and future leverage is high in both samples, which suggests that leverage ratios are persistent, consistent with imprinting theory.

--- Insert Table 2 about here ---

\subsection{Multivariate analysis}

Table 3 examines the determinants of leverage using the full sample and reports GEEs with robust standard errors. Model 1 includes only control variables, in Model 2 we add the For-profit social enterprise dummy variable and in Model 3 we add the interaction term between the Forprofit social enterprise dummy variable and Time.

\section{--- Insert Table 3 about here ---}

Hypothesis 1 stated that over time, for-profit social enterprises' capital structures would consistently include less debt than commercial enterprises' capital structures. Table 3, Model 2, shows that for-profit social enterprises have on average significantly lower leverage ratios than 
matched commercial enterprises. The for-profit social enterprise dummy variable $(\beta=-0.078 ; p<$ 0.01 ) suggests that leverage is on average 7.8 percentage points lower for for-profit social enterprises relative to commercial enterprises. In addition, the interaction between the for-profit social enterprise dummy variable and time, in Model 3, demonstrates that this level effect is particularly large early in time (i.e., initial leverage ratios are 12.3 percentage points lower for forprofit social enterprises relative to commercial enterprises) but gradually decreases over time ( $\beta=$ $0.011 ; \mathrm{p}<0.05)$

Figure 1 plots the interaction effect from Model 3. Taking all control variables at their means, this figure illustrates that the leverage ratio of for-profit social enterprises shows an increasing trend from 0.15 to 0.17 , while the leverage ratio of commercial enterprises shows a stronger decreasing trend from up to 0.25 to close to $0.20{ }^{11}$ Still, the leverage ratio of for-profit social enterprises remains significantly lower than that of commercial enterprises. Our findings are also economically significant because, over the time frame of our study, for-profit social enterprises have approximately $40 \%$ to $13 \%$ lower leverage ratios than matched commercial enterprises. Overall, our evidence supports Hypothesis 1.

--- Insert Figure 1 about here ---

In all model specifications of Table 3, the control variables indicate that consistent with previous research, profitability and subsidies are negatively correlated with leverage, while tangibility, growth, and size are positively correlated with leverage (e.g., Degryse et al., 2012). While the above results focused on the differences in the level of leverage between for-profit social enterprises and

\footnotetext{
${ }^{11}$ We can only plot predicted leverage values from time $=2$ onwards and up to time $=9$ because we use lagged control variables (and for measuring lagged growth we also need an additional year of historical data). One might be tempted to argue that (all else equal) the leverage of for-profit social and commercial enterprises will eventually become similar over time - given the trend in our data. However, we warn against the dangers of extrapolation outside the time frame of our study (Neter et al., 1996). We can only observe that at the end of the timeframe of our study for-profit social enterprises still have 13\% lower leverage ratios than commercial enterprises and this difference is statistically significant.
} 
commercial enterprises over time, they do not focus on potential differences in the sensitivity of future leverage ratios to initial leverage ratios for for-profit social enterprises and commercial enterprises. We next delve deeper into this issue.

Table 4 focuses on the determinants of leverage and reports GEEs with robust standard errors using the samples of for-profit social enterprises and commercial enterprises separately. Model 1 includes only initial leverage and the control variables using data of for-profit social enterprises only, while Model 2 includes only initial leverage and the control variables but uses data of commercial enterprises only. In Model 3 and Model 4, we add the interaction between initial leverage and time to Model 1 and 2, respectively.

\section{--- Insert Table 4 about here ---}

The results in Model 1 suggest that for for-profit social enterprises initial leverage is on average a significant predictor of future leverage over the entire time frame of our study $(\beta=0.548 ; p<$ 0.001). Similarly, the results in Model 2 suggest that for commercial enterprises initial leverage is on average a significant predictor of future leverage over the entire time frame of our study $(\beta=$ 0.600; $p<0.001)$. Qualitative comparisons of the coefficients from Model 1 and Model 2 suggest that initial leverage is a stronger predictor of future leverage for commercial enterprises than forprofit social enterprises but this does not provide statistical evidence (e.g., Wade et al., 2006). We use seemingly unrelated estimation to tests for differences in the size of the coefficients of initial leverage across regression models by calculating a single, simultaneous covariance matrix. Model 1 and Model 2 fail to find a significant difference in the relationship between initial leverage and future leverage over the entire time frame of our study for for-profit social enterprises and commercial enterprises.

However, Models 1 and Model 2 focus on the average relationship between initial leverage and future leverage over the entire time frame of our study and as such can hide important dynamics 
over time. Thus, these models do not provide a direct test of Hypothesis 2, which stated that the influence of initial leverage ratios on future leverage would remain stronger over time among forprofit social enterprises than among matched commercial enterprises. Model 3 suggests that the relationship between initial leverage and future leverage for for-profit social enterprises is high and remains broadly constant over time because the interaction term between initial leverage and time is not significant $(\beta=-0.012 ; p>0.10)$. Model 4 , however, suggests that the relationship between initial leverage and future leverage for commercial enterprises is particularly strong in the early years, but gradually diminishes over time because the interaction term between initial leverage and time is negative and significant $(\beta=-0.072 ; p<0.001)$. The differences in the effects of initial leverage and the interaction between initial leverage and time across the for-profit social enterprise model and commercial enterprise model are also statistically significant.

Figure 2 provides additional evidence by plotting the estimated coefficients (and error bands) of initial leverage on future leverage for for-profit social enterprises and commercial enterprises using cross-sectional regressions at different time points. ${ }^{12}$ While the estimated relationship between initial leverage and future leverage decreases fast for commercial enterprises, the relationship between initial leverage and future leverage remains high over the entire time frame of the study for for-profit social enterprises. Again these differences between for-profit social enterprises and commercial enterprises are economically significant. At the end of the time frame of our study, the relationship between initial leverage (at $t=0$ ) and current leverage (at $t=9$ ) is 0.99 for for-profit social enterprises, while it is 0.24 or approximately 4 times lower for matched commercial enterprises. Combined, this evidence suggests that leverage ratios are more persistent

\footnotetext{
12 Thus, we run Model 3 and 4 from Table 4 only using data at time $=2$, time $=3$, up to time $=9$, respectively. We can only estimate and plot the relationship between initial leverage $(\mathrm{t}=0)$ and future leverage at time $+\mathrm{n}$, where $\mathrm{n}$ is equal to or larger than 2, because we use lagged control variables and for measuring lagged growth we also need an additional year of historical data.
} 
for for-profit social enterprises relative to commercial enterprises in the long run, which supports Hypothesis 2.

\section{--- Insert Figure 2 about here ---}

A final noteworthy observation from Table 4 is that the traditional capital structure variables and other controls generally do not exhibit significantly different effects for for-profit social enterprises relative to commercial enterprises. ${ }^{13}$

\section{Discussion}

We have examined capital structure differences between young for-profit social and commercial enterprises. The use of financial resources is a critical but under examined area in the literature on social and hybrid enterprising (Doherty et al., 2014). We have developed and tested a new perspective based on imprinting theory and the social entrepreneurship literature for how capital structure differs between for-profit social and commercial enterprises over time. For this purpose, we used a unique matched longitudinal dataset of for-profit social enterprises (Flemish SPCs) and commercial enterprises.

Our findings based on SPCs are relevant to the emerging body of work on B Corps in particular and other prosocial hybrids in general. Indeed, SPCs and B Corps share common features such as having a for-profit legal form and dual mission based on economic and social goals, which generate common differences compared to commercial enterprises (Fosfuri et al., 2016). By having to generate both financial and social returns, SPCs, B Corps, and other hybrid categories have in common the need to use prosocial cost-benefit analysis (Miller et al., 2012) for major decisions

\footnotetext{
${ }^{13}$ One potential concern related our firm-level regressions reported above is that the results are driven by observations from large industries. To address this concern, we run weighted least squares models as a robustness test, where the weight of each observation is the inverse of the number of observations in each industry, so that each industry receives equal weight in the estimation. Results remain qualitatively similar.
} 
such as capital structure. Given that SPCs and B Corps share similar main characteristics, our findings are important for B Corps and similar hybrid categories. We highlight below the contributions of this study for the literature on social entrepreneurship and entrepreneurial finance.

\subsection{Contributions to literature on social entrepreneurship}

Our study generates three main contributions to the domain of social entrepreneurship by focusing on the link between prosociality and capital structure decisions. First, our study contributes to the literature that emphasizes substantive differences between social and commercial enterprises (Santos, 2012) and how these differences likely generate distinct expectations of entrepreneurial behavior (Estrin et al., 2016; Wry and York, 2017). Scholars have questioned whether social enterprises require specific theories or whether existing theories that explain and predict the behavior of commercial enterprises apply to the context of social entrepreneurship. Past research has argued that social entrepreneurship is not a distinct type of entrepreneurship but just a different context in which existing types of entrepreneurship take place, and thus social enterprises would not require specific theories (Dacin et al., 2010). Yet, social enterprises often face unique challenges because they have to achieve simultaneously social returns by creating social value as well as financial returns by creating economic value (Battilana and Dorado, 2010). Our study suggests that differences in leverage between for-profit social enterprises and matched commercial enterprises derive from imprints of prosocial organizing of capital structure that go beyond financial preferences. Thus, for-profit social enterprises (and similar hybrid organizations) may require theories adjusted to their specific context.

Second, our study extends the literature on imprinting theory in the domain of social entrepreneurship by revealing that imprinting can be stronger for for-profit social enterprises than for commercial enterprises. Particularly, our findings regarding "sensitivity effects" indicate that 
the strength of imprints over time varies significantly between for-profit social and commercial enterprises. Previous research has suggested that imprints may decay over time, due to several factors such as the simple passing of time, entrepreneurial turnover, and poor performance (e.g., Simsek et al., 2015). Our study shows that the relationship between initial leverage and future leverage remains much stronger over time for for-profit social enterprises compared to commercial enterprises. These findings extend prior research on imprinting in the field of social entrepreneurship (Battilana et al., 2015) by addressing not only the context within social enterprises but also between social and commercial enterprises.

Third, we shed light on the link between prosociality and capital structure by introducing a new perspective on how capital structure depends on prosocial preferences. There are unique challenges in reconciling for-profit and social goals that characterize hybrid organizations (e.g., Battilana and Lee, 2014). These challenges can be particularly salient among for-profit social enterprises given their formal commitment to generate both economic and social returns (Kistruck et al., 2013). For-profit social enterprises are especially inclined to using prosocial cost-benefit analysis, which recognizes the need for both financial and social results (Miller et al., 2012). To reconcile both economic and social purposes, long-term investments are often needed to produce continuity of improved productive and social systems over time (Nicholls and Opal, 2005). Longterm orientation often characterizes new firms emphasizing social responsibility (Wang and Bansal, 2012). Social entrepreneurship typically seeks to address social and environmental problems by producing sustained change for current and future generations (Dean and McMullen, 2007). By recognizing prosocial utility maximization based on a different set of utilities in addition to profit, such as entrepreneur's preferences for sources of capital that enable greater flexibility to reconcile economic and social goals, our study provides a basis towards a better understanding of 
how for-profit social entrepreneurs might optimize their capital structures differently than commercial counterparts in order to pursue both economic and social goals.

\subsection{Contributions to literature on entrepreneurial finance}

Traditional capital structure theories, namely, pecking order theory (Myers, 1984; Myers and Majluf, 1984) and static trade-off theory (Modigliani and Miller, 1963; Kraus and Litzenberger, 1973; Jensen and Meckling, 1976), are based on the premise that entrepreneurs maximize their utility by maximizing the financial value of their firms or their own wealth. Multiple empirical studies have tested these theories for entrepreneurial firms (Cassar, 2004; Cosh et al., 2009). While the traditional theories are well-examined, the evidence on how non-financial preferences of entrepreneurs affect capital structure is scarce. This lack of research is in stark contrast to the growing importance of different forms of enterprises with social and environmental goals.

We started to fill this gap by comparing the capital structure of for-profit social and commercial enterprises. Our study shows that even after controlling for traditional capital structure determinants, for-profit social enterprises have significantly lower leverage ratios than matched commercial enterprises. This finding suggests that the former's prosocial preferences play an important role in the amount of debt that firms attract over time. We also investigate differences in the stability of leverage between for-profit social enterprises and commercial enterprises over time. Although standard capital structure theories predict dynamic leverage ratios, recent empirical evidence shows that leverage ratios remain surprisingly persistent (Lemmon et al. 2008; Hanssens et al. 2016). Possible theoretical explanations for this puzzling effect are yet largely unexplored. Our findings confirm that leverage ratios of commercial enterprises remain persistent but we also show that the leverage ratios of for-profit social enterprises remain particularly persistent. 
Consequently, prosocial preferences of entrepreneurs significantly influence capital structure stability. In this way, our study provides important insights for entrepreneurial finance scholars who want to extend traditional capital structure theories by taking into account the different objectives of entrepreneurs besides profit maximization.

\subsection{Limitations and additional future research directions}

Limitations of this study represent opportunities for future research. First, our study has focused on capital structure differences between young for-profit social and commercial enterprises with up to 12 years of operation. Future research is needed to examine different age groups to further understand how capital structure differences emerge and evolve over different stages of company development. Moreover, future studies can examine a broader set of social enterprises, including not only for-profit social enterprises but also nonprofit organizations, to further understand how differences in entrepreneurial preferences influence capital structure. New studies may also investigate for-profit social enterprises in different countries to probe the influence of a broad set of institutional factors (e.g., regulatory, political, and economic) in affecting social enterprises' financial structure.

Moreover, while we compared capital structures between for-profit social and commercial enterprises, both sets of entrepreneurs have to make many other important decisions. Our framework of "level" and "sensitivity" effects that draws on the imprinting and social entrepreneurship literature to compare social and commercial enterprises can be applied to several other decisions. For instance, our framework might be helpful to understand differences in geographical expansion, dividend payments, and innovation by focusing on "level effects" (such as differences in export intensity, dividends, and R\&D expenditures) and "sensitivity effects" (such as the persistence of internationalization activities, dividend payments, and R\&D expenditures) to 
better understand the extent to which various decisions and outcomes differ between social and commercial enterprises. Future research should investigate the financial options available to forprofit social enterprises such as B Corps and Benefit Corporations, their use of different financial capital sources such as use of equity, as well as emergent financial organizations providing impact investing to hybrid organizations (Davis and Braunholtz-Speight, 2016; Gustafsson-Wright et al., 2015; Haigh et al., 2015; Miller and Wesley II, 2010).

\subsection{Implications for practice}

Entrepreneurs generally lack sufficient internal funds and thus require external financial resources, and debt financing in particular, to form their ventures (Cassar, 2004). Capital structure decisions are also important because they fundamentally shape venture survival prospects and the ability of entrepreneurs to scale their ventures (Åstebro and Bernhardt, 2003; Robb and Robinson, 2014). Our results suggest that for-profit social entrepreneurs do use external sources of debt financing as a non-trivial source of financing; on average 15 to $17 \%$ of assets are financed by debt. Still, our findings also suggest that entrepreneurs in for-profit social enterprises use $40 \%$ to $13 \%$ less debt financing than entrepreneurs in similar commercial enterprises, even after controlling for the traditional determinants (e.g., profitability, collateral) that impact entrepreneurs' use of and access to debt financing. While this suggests that for-profit social entrepreneurs potentially leave financial value on the table (e.g., tax advantages related to debt finance), our study does not argue that for-profit social entrepreneurs should use more debt financing. Indeed, the more limited use of debt financing by social entrepreneurs can be optimal when combining their financial goals with their social goals. Nevertheless, by using less debt financing, for-profit social entrepreneurs may experience particular difficulties in scaling their ventures beyond what is possible through the use of internal funds. 
This study further informs policy-makers and bankers about the need to have financing sources for young for-profit social enterprises that fit with their longer time perspective and hybrid goals. External sources of equity financing are generally unavailable for the average entrepreneurial venture. Indeed, only one for-profit social enterprise in our sample raised venture capital finance. Thus, financing decisions primarily revolve around using internal financing and debt financing. When entrepreneurs are unwilling to raise external financing they can still constrain venture growth, which is generally viewed as an undesirable outcome. Governments have generally tried to support the growth of social ventures by providing subsidy financing. Our findings indeed suggest that for-profit social enterprises use more subsidy financing ( $3 \%$ of total assets) relative to commercial ventures (where subsidies are negligible). Still, a potential route that governments and bankers could consider is to provide access to specific forms of debt financing that reduce the possible conflict between strictly timed, fixed debt payments and future investments in social projects. For instance, such debt instruments may have more flexible repayment schedules conditional upon the creation of social value.

\section{Conclusion}

We conducted one of the first investigations of capital structure differences between young for-profit social and commercial enterprises. Our research highlights limitations of traditional entrepreneurial finance perspectives in explaining capital structure differences between for-profit social and commercial enterprises over time. We therefore develop a new theoretical rationale to understand capital structure differences between commercial and for-profit social enterprises over time. Our study opens important avenues for future researchers by revealing that existing capital structure theories need modification for the context of for-profit social enterprises. 


\section{References}

Akerlof, G. A., 1970. The market for "lemons": quality uncertainty and the market mechanism. Quarterly Journal of Economics. 84 (3), 488-500.

Allison, T. H., Davis, B. C., Short, J. C., Webb, J. W., 2015. Crowdfunding in a prosocial microlending environment: examining the role of intrinsic versus extrinsic cues. Entrepreneurship Theory and Practice. 39 (1), 53-73.

Altman, E. I., 1984. A further empirical investigation of the bankruptcy cost question. Journal of Finance. 39 (4), 1067-1089.

André, R., 2012. Assessing the accountability of the benefit corporation: will this new gray sector organization enhance corporate social responsibility? Journal of Business Ethics. 110 (1), 133-150.

Åstebro, T., Bernhardt, I., 2003. Start-up financing, owner characteristics, and survival. Journal of Economics and Business. 55 (4), 303-319.

Austin, J., Stevenson, H., Wei-Skillern, J., 2006. Social and commercial entrepreneurship: same, different, or both? Entrepreneurship Theory and Practice. 30 (1), 1-22.

B Corporation, 2017. https://www.bcorporation.net/what-are-b-corps/the-non-profit-behind-bcorps/our-history Accessed on September 23, 2017.

Bacq, S., Lumpkin, G. T., 2014. Can social entrepreneurship researchers learn from family business scholarship? A theory-based future research agenda. Journal of Social Entrepreneurship. 5 (3), 270-294.

Ballinger, G. A., 2004. Using generalized estimating equations for longitudinal data analysis. Organizational Research Methods. 7 (2), 127-150.

Baron, D. P., 2007. Corporate social responsibility and social entrepreneurship. Journal of Economics and Management Strategy. 16 (3), 683-717. 
Baron, J. N., Burton, M. D., Hannan, M. T., 1999a. Engineering bureaucracy: the genesis of formal policies, positions, and structures in high-technology firms. Journal of Law, Economics, and Organization. 15 (1), 1-41.

Baron, J. N., Hannan, M. T., Burton, M. D., 1999b. Building the iron cage: determinants of managerial intensity in the early years of organizations. American Sociological Review. $64(4), 527-547$.

Battilana, J., Dorado, S., 2010. Building sustainable hybrid organizations: the case of commercial microfinance organizations. Academy of Management Journal. 53 (6), 1419-1440.

Battilana, J., Lee, M., 2014. Advancing research on hybrid organizing - insights from the study of social enterprises. Academy of Management Annals. 8 (1), 397-441.

Battilana, J., Sngul, M., Pache, A.-C., Model, J., 2015. Harnessing productive tensions in hybrid organizations: the case of work integration social enterprises. Academy of Management Journal. 58 (6), 1658-1858.

Beckman, C. M., Burton, M. D., 2008. Founding the future: path dependence in the evolution of top management teams from founding to IPO. Organization Science. 19 (1), 3-24.

Benefit Corporation, 2017. http://benefitcorp.net/businesses/benefit-corporation-reportingrequirements Accessed on September 23, 2017.

Benz, M., 2005. Not for the profit, but for the satisfaction? Evidence on worker well-being in non-profit firms. Kyklos. 58 (2), 155-176.

Berger, A. N., Udell, G. F., 1998. The economics of small business finance: the roles of private equity and debt markets in the financial growth cycle. Journal of Banking and Finance. 22 (6-8), 613-673.

Boeker, W., 1989. Strategic change: the effects of founding and history. Academy of Management Journal. 32 (3), 489-515. 
Brav, O., 2009. Access to capital, capital structure, and the funding of the firm. Journal of Finance. 64 (1), 263-308.

Bromiley, P., 2005. The Behavioral Foundations of Strategic Management. John Wiley \& Sons.

Bruton, G., Khavul, S., Siegel, D., Wright, M., 2015. New financial alternatives in seeding entrepreneurship: microfinance, crowdfunding, and peer-to-peer innovations. Entrepreneurship Theory and Practice. 39 (1), 9-26.

Calic, G., Mosakowski, E., 2016. Kicking off social entrepreneurship: how a sustainability orientation influences crowdfunding success. Journal of Management Studies. 53 (5), 738-767.

Cassar, G., 2004. The financing of business start-ups. Journal of Business Venturing. 19 (2), 261 283.

Certo, S. T., Miller, T., 2008. Social entrepreneurship: key issues and concepts. Business Horizons. 51 (4), 267-271.

Coleman, S., Robb, A., 2009. A comparison of new firm financing by gender: evidence from the Kauffman firm survey data. Small Business Economics. 33 (4), 397-411.

Cooney, K., 2011. An exploratory study of social purpose business models in the United States. Nonprofit and Voluntary Sector Quarterly. 40 (1), 185-196.

Cosh, A., Cumming, D., Hughes, A., 2009. Outside entrepreneurial capital. Economic Journal. 119 (540), 1494-1533.

Crucke, S., Knockaert, M., 2016. When stakeholder representation leads to faultlines. A study of board service performance in social enterprises. Journal of Management Studies. 53 (5), 768-793. 
Dacin, P. A., Dacin, M. T., Matear, M., 2010. Social entrepreneurship: why we don't need a new theory and how we move forward from here. Academy of Management Perspectives. 24 (3), 37-57.

Davis, M., Braunholtz-Speight, T., 2016. Financial innovation today: towards economic resilience. Available from https://scholar.google.com/scholar?hl=en\&as_sdt=0\%2C22\&q=Financial+Innovation + To $\underline{\text { day } \% 3 \mathrm{~A}+\text { Towards }+ \text { Economic }+ \text { Resilience } \& b \operatorname{tnG}}=$. Accessed Friday, November 3, 2017

Dean, T. J., McMullen, J. S., 2007. Toward a theory of sustainable entrepreneurship: reducing environmental degradation through entrepreneurial action. Journal of Business Venturing. $22(1), 50-76$.

Defourny, J., Nyssens, M., 2008. Social enterprise in Europe: recent trends and developments. Social Enterprise Journal. 4 (3), 202-228.

Degryse, H., de Goeij, P., Kappert, P., 2012. The impact of firm and industry characteristics on small firms' capital structure. Small Business Economics. 38 (4), 431-447.

Doherty, B., Haugh, H., Lyon, F., 2014. Social enterprises as hybrid organizations: a review and research agenda. International Journal of Management Reviews. 16 (4), 417-436.

Dushnitsky, G., Guerini, M., Piva, E., Rossi-Lamastra, C., 2016. Crowdfunding in Europe: determinants of platform creation across countries. California Management Review. 58 (2), 44-71.

Ebrahim, A., Battilana, J., Mair, J., 2014. The governance of social enterprises: mission drift and accountability challenges in hybrid organizations. Research in Organizational Behavior. 34 81-100. 
Eisenhardt, K. M., Schoonhoven, C. B., 1990. Organizational growth: linking founding team, strategy, environment, and growth among U.S. semiconductor ventures, 1978-1988. Administrative Science Quarterly. 35 (3), 504-529.

Estrin, S., Mickiewicz, T., Stephan, U., 2016. Human capital in social and commercial entrepreneurship. Journal of Business Venturing. 31 (4), 449-467.

Fedele, A., Miniaci, R., 2010. Do social enterprises finance their investments differently from for-profit firms? The case of social residential services in Italy. Journal of Social Entrepreneurship. 1 (2), 174-189.

Fitzmaurice, G. M., Laird, N. M., Ware, J. H., 2012. Applied Longitudinal Analysis. John Wiley \& Sons.

Fleming, L., Sorenson, O., 2016. Financing by and for the masses: an introduction to the special issue on crowdfunding. California Management Review. 58 (2), 5-19.

Fosfuri, A., Giarratana, M. S., Roca, E., 2016. Social business hybrids: demand externalities, competitive advantage, and growth through diversification. Organization Science. 27 (5), $1275-1289$.

Foster, W., Bradach, J., 2005. Should nonprofits seek profits? Harvard Business Review. 83 (2), 92-100.

Frank, M. Z., Goyal, V. K., 2009. Capital structure decisions: which factors are reliably important? Financial Management. 38 (1), 1-37.

Gehman, J., Grimes, M., 2016. Hidden badge of honor: how contextual distinctiveness affects category promotion among certified B corporations. Academy of Management Journal. (Forthcoming).

Germak, A. J., Robinson, J. A., 2014. Exploring the motivation of nascent social entrepreneurs. Journal of Social Entrepreneurship. 5 (1), 5-21. 
Gustafsson-Wright, E., Gardiner, S., Putcha, V., 2015. The potential and limitations of impact bonds: lessons from the first five years of experience worldwide. Global Economy and Development at Brookings. Available from https://www.brookings.edu/wpcontent/uploads/2015/07/impact-bondsweb.pdf . Accessed November 3, 2017.

Haigh, N., Kennedy, E. D., Walker, J., 2015. Hybrid organizations as shape-shifters: altering legal structure for strategic gain. California Management Review. 57 (3), 59-82.

Hannan, M. T., Burton, M. D., Baron, J. N., 1996. Inertia and change in the early years: employment relations in young, high technology firms. Industrial and Corporate Change. $5(2), 503-536$.

Hanssens, J., Deloof, M., Vanacker, T., 2016. The evolution of debt policies: new evidence from business startups. Journal of Banking and Finance. 65, 120-133.

Haymore, S. J., 2011. Public(ly oriented) companies: B corporations and the Delaware stakeholder provision dilemma. Vanderbilt Law Review. 64 (4), 1311-1346.

Heyman, D., Deloof, M., Ooghe, H., 2008. The financial structure of private held Belgian firms. Small Business Economics. 30 (3), 301-313.

Hiller, J. S., 2013. The benefit corporation and corporate social responsibility. Journal of Business Ethics. 118 (2), 287-301.

Hoang, H., Antoncic, B., 2003. Network-based research in entrepreneurship: a critical review. Journal of Business Venturing. 18 (2), 165-187.

Jensen, M. C., 1986. Agency costs of free cash flow, corporate finance, and takeovers. American Economic Review, 76(2), 323-329.

Jensen, M. C., Meckling, W. H., 1976. Theory of the firm: managerial behavior, agency costs and ownership structure. Journal of Financial Economics. 3 (4), 305-360. 
Katila, R., Ahuja, G., 2002. Something old, something new: a longitudinal study of search behavior and new product introduction. Academy of Management Journal. 45 (6), 1183 1194.

Kerlin, J. A., 2013. Defining social enterprise across different contexts: a conceptual framework based on institutional factors. Nonprofit and Voluntary Sector Quarterly. 42, 84-108.

King, G., Nielsen, R., 2016. Why propensity scores should not be used for matching. Available from https://gking.harvard.edu/files/gking/files/psnot.pdf. Accessed October 5, 2017.

Kistruck, G. M., Beamish, P. W., Qureshi, I., Sutter, C. J., 2013. Social intermediation in base-ofthe-pyramid markets. Journal of Management Studies, 50(1), 31-66.

Kraus, A., Litzenberger, R. H., 1973. A state-preference model of optimal financial leverage. Journal of Finance. 28 (4), 911-922.

Kwon, S. W., Ruef, M., 2017. The imprint of labor markets on entrepreneurial performance. Journal of Business Venturing. 32 (6), 611-626

Lemmon, M. L., Roberts, M. R., Zender, J. F., 2008. Back to the beginning: persistence and the cross-section of corporate capital structure. Journal of Finance. 63 (4), 1575-1608.

Lerner, J., 1999. The government as venture capitalist: the long-run impact of the SBIR program. Journal of Business. 72 (3), 285-318.

Mair, J., Battilana, J., Cardenas, J., 2012. Organizing for society: a typology of social entrepreneuring models. Journal of Business Ethics, 111(3), 353-373.

Marquis, C., Tilcsik, A., 2013. Imprinting: toward a multilevel theory. Academy of Management Annals. 7 (1), 195-245.

McMullen, J. S., Dimov, D., 2013. Time and the entrepreneurial journey: the problems and promise of studying entrepreneurship as a process. Journal of Management Studies. 50 (8), 1481-1512. 
Megginson, W. L., Weiss, K. A., 1991. Venture capitalist certification in initial public offerings. Journal of Finance. 46 (3), 879-903.

Michaelas, N., Chittenden, F., Poutziouris, P., 1999. Financial policy and capital structure choice in U.K. SMEs: empirical evidence from company panel data. Small Business Economics. $12(2), 113-130$.

Miller, D., Le Breton-Miller, I., 2011. Governance, social identity, and entrepreneurial orientation in closely held public companies. Entrepreneurship Theory and Practice. 35 (5), 1051-1076.

Miller, T. L., Grimes, M. G., McMullen, J. S., Vogus, T. J., 2012. Venturing for others with heart and head: how compassion encourages social entrepreneurship. Academy of Management Review. 37 (4), 616-640.

Miller, T. L., Wesley II, C. L., 2010. Assessing mission and resources for social change: an organizational identity perspective on social venture capitalists' decision criteria. Entrepreneurship Theory and Practice. 34 (4), 705-733.

Modigliani, F., Miller, M. H., 1963. Corporate income taxes and the cost of capital: a correction. American Economic Review. 53 (3), 433-443.

Moss, T. W., Neubaum, D. O., Meyskens, M., 2015. The effect of virtuous and entrepreneurial orientations on microfinance lending and repayment: a signaling theory perspective. Entrepreneurship Theory and Practice. 39 (1), $27-52$.

Myers, S. C., 1977. Determinants of corporate borrowing. Journal of Financial Economics. 5 (2), $147-175$.

Myers, S. C., 1984. The capital structure puzzle. Journal of Finance. 39 (3), 575-592.

Myers, S. C., Majluf, N. S., 1984. Corporate financing and investment decisions when firms have information that investors do not have. Journal of Financial Economics. 13 (2), 187-221. 
Neter, J., Kutner, M., Wasserman, W., Nachtsheim, C., 1996. Applied Linear Statistical Models. McGraw-Hill/Irwin.

Nicholls, A., 2010. Institutionalizing social entrepreneurship in regulatory space: Reporting and disclosure by community interest companies. Accounting, Organizations and Society. 35 (4), 394-415.

Nicholls, A., Opal, C., 2005. Fair Trade: Market-Driven Ethical Consumption. SAGE Publications.

Ocasio, W., 1997. Towards an attention-based view of the firm. Strategic Management Journal. $18,187-206$.

Opler, T. C., Titman, S., 1994. Financial distress and corporate performance. Journal of Finance. $49(3), 1015$.

Puri, M., Zarutskie, R., 2012. On the life cycle dynamics of venture-capital- and non-venturecapital-financed firms. Journal of Finance. 67 (6), 2247-2247.

Rajan, R. G., Zingales, L., 1995. What do we know about capital structure? Some evidence from international data. Journal of Finance. 50 (5), 1421-1460.

Rawhouser, H., Cummings, M., Crane, A., 2015. Benefit corporation legislation and the emergence of a social hybrid category. California Management Review. 57 (3), 13-35.

Reiser, D. B., 2010. Blended enterprise and the dual mission dilemma. Vermont Law Review. 35 (1), 105-116.

Robb, A. M., Fairlie, R. W., Robinson, D. T., 2009. Financial capital injections among new black and white business ventures: evidence from the Kauffman Firm Survey. Unpublished paper, University of California, Santa Cruz and Duke University.

Robb, A. M., Robinson, D. T., 2014. The capital structure decisions of new firms. Review of Financial Studies. 27 (1), 153-179. 
Santos, F. M., 2012. A positive theory of social entrepreneurship. Journal of Business Ethics. 111 (3), 335-351.

Sapienza, H. J., Korsgaard, M. A., Forbes, D. P., 2003. The self-determination motive and entrepreneurs' choice of financing. In: Katz, J. A., \& Shepherd, D. A. (Eds.), Cognitive Approaches to Entrepreneurship Research, Emerald Group Publishing, pp. 105-138.

Scherr, F. C., Hulburt, H. M., 2001. The debt maturity structure of small firms. Financial Management. 30 (1), 85-111.

Shadish, W. R., 2002. Revisiting field experimentation: field notes for the future. Psychological Methods. 7 (1), 3-18.

Short, J. C., Moss, T. W., Lumpkin, G. T., 2009. Research in social entrepreneurship: past contributions and future opportunities. Strategic Entrepreneurship Journal. 3 (2), 161-194. Shyam-Sunder, L., Myers, S. C., 1999. Testing static tradeoff against pecking order models of capital structure. Journal of Financial Economics. 51 (2), 219-244.

Simsek, Z., Fox, B. C., Heavey, C., 2015. "What's past is prologue": a framework, review, and future directions for organizational research on imprinting. Journal of Management. 41 (1), 288-317.

Slawinski, N., Bansal, P., 2012. A matter of time: the temporal perspectives of organizational responses to climate change. Organization Studies. 33 (11), 1537-1563.

Slawinski, N., Bansal, P., 2015. Short on time: intertemporal tensions in business sustainability. Organization Science. 26 (2), 531-549.

Sogorb-Mira, F., 2005. How SME uniqueness affects capital structure: evidence from a 19941998 Spanish data panel. Small Business Economics. 25 (5), 447-457. 
Stevens, R., Moray, N., Bruneel, J., 2015a. The social and economic mission of social enterprises: dimensions, measurement, validation, and relation. Entrepreneurship Theory and Practice. 39 (5), 1051-1082.

Stevens, R., Moray, N., Bruneel, J., Clarysse, B., 2015b. Attention allocation to multiple goals: the case of for-profit social enterprises. Strategic Management Journal. 36 (7), 1006-1016. Stinchcombe, A. L., 1965. Social structure and organizations. In: March, J. G. (Ed.), Handbook of Organizations, pp. 142-193.

Sunley, P., Pinch, S., 2012. Financing social enterprise: social bricolage or evolutionary entrepreneurialism? Social Enterprise Journal. 8 (2), 108-122.

Szymańska, A., Van Puyvelde, S., Jegers, M., 2015. Capital structure of social purpose companies - a panel data analysis. Journal of Sustainable Finance \& Investment. 5 (4), 234-254.

Thébaud, S., 2015. Business as Plan B: institutional foundations of gender inequality in entrepreneurship across 24 industrialized countries. Administrative Science Quarterly. 60 (4), 671-711.

Titman, S., 1984. The effect of capital structure on a firm's liquidation decision. Journal of Financial Economics. 13 (1), 137-151.

Van de Ven, A. H., 2007. Engaged scholarship: a guide for organizational and social research. Oxford University Press.

Vanacker, T., Forbes, D. P., 2016. Disentangling the multiple effects of affiliate reputation on resource attraction in new firms. Organization Science. 27 (6), 1525-1547.

Wade, J., B. , O’Reilly III, C. A., Pollock, T., G., 2006. Overpaid CEOs and underpaid managers: fairness and executive compensation. Organization Science. 17 (5), 527-544. 
Wang, T., Bansal, P., 2012. Social responsibility in new ventures: profiting from a long-term orientation. Strategic Management Journal. 33 (10), 1135-1153.

Wry, T., York, J. G., 2017. An identity-based approach to social enterprise. Academy of Management Review. 42 (3), 437-460. 
Table 1. Description of the one-to-one matched sample of SEs and CEs in the year of matching

Nmbr. of firms by indus try:

$\underline{\text { SEs }}$

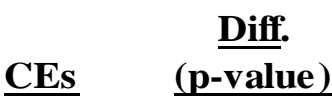

Agriculture, forestry and fishing

Manufacturing

Water supply, sewerage, waste management

Construction

Wholesale and retail trade

Transportation and storage

Accommodation and food service activities

Information and communication

Financial and insurance activities

Real estate activities

Professional, scientific and technical activities

Administrative and support service activities

Education

Human health and social work activities

Arts, entertainment and recreation

Other service activities

Total nmbr. of firms

Firm age (in years):

Median

1.00

1.00

0.94

Mean

2.16

2.17

0.98

S.D.

2.57

2.56

Firm size (total assets in 1000 euro):

Median

150

150

0.99

Mean

1,143

716

0.44

S.D.

5,493

2,575

Notes. We matched each SE to a $\mathrm{CE}$ at the time the SE enters the dataset based on four characteristics, namely, geographical region (Flanders), industry, firm age, and firm size (total assets). Significance levels report differences between SEs and matched CEs using Mann-Whitney U Tests (Median) and t-tests (Mean). 


\begin{tabular}{|c|c|c|c|c|c|c|c|c|c|c|c|}
\hline \multicolumn{12}{|l|}{ Panel A: SEs } \\
\hline & Mean & S.D. & 1 & 2 & 3 & 4 & 5 & 6 & 7 & 8 & 9 \\
\hline 1 Leverage & 0.15 & 0.26 & 1.00 & & & & & & & & \\
\hline 2 Initial leverage & 0.15 & 0.25 & 0.53 & 1.00 & & & & & & & \\
\hline 3 Time & 4.73 & 2.23 & -0.02 & -0.08 & 1.00 & & & & & & \\
\hline 4 Profitability & -0.02 & 0.34 & -0.16 & 0.07 & -0.04 & 1.00 & & & & & \\
\hline 5 Tangibility & 0.25 & 0.32 & 0.38 & 0.33 & -0.04 & -0.03 & 1.00 & & & & \\
\hline 6 Growth & 1.17 & 0.54 & -0.01 & -0.05 & -0.22 & 0.37 & -0.10 & 1.00 & & & \\
\hline 7 Size & 5.79 & 1.67 & 0.03 & 0.11 & 0.19 & 0.39 & 0.18 & 0.12 & 1.00 & & \\
\hline 8 Subsidies & 0.03 & 0.24 & -0.06 & -0.06 & 0.10 & 0.04 & -0.08 & 0.02 & 0.25 & 1.00 & \\
\hline 9 Prop. male & 0.20 & 0.35 & 0.15 & -0.04 & -0.02 & -0.10 & -0.04 & -0.03 & 0.03 & -0.06 & 1.00 \\
\hline 10 Prop. highly educated & 0.14 & 0.31 & -0.01 & -0.09 & 0.12 & 0.09 & -0.15 & 0.06 & 0.17 & 0.08 & 0.11 \\
\hline \multicolumn{12}{|l|}{ Panel B: CEs } \\
\hline & Mean & S.D. & 1 & 2 & 3 & 4 & 5 & 6 & 7 & 8 & 9 \\
\hline 1 Leverage & 0.23 & 0.26 & 1.00 & & & & & & & & \\
\hline 2 Initial leverage & 0.25 & 0.28 & 0.65 & 1.00 & & & & & & & \\
\hline 3 Time & 4.85 & 2.20 & -0.09 & 0.02 & 1.00 & & & & & & \\
\hline 4 Profitability & 0.09 & 0.24 & -0.18 & -0.12 & 0.05 & 1.00 & & & & & \\
\hline 5 Tangibility & 0.37 & 0.31 & 0.51 & 0.44 & -0.04 & -0.13 & 1.00 & & & & \\
\hline 6 Growth & 1.10 & 0.36 & 0.03 & -0.13 & -0.09 & 0.27 & -0.01 & 1.00 & & & \\
\hline 7 Size & 5.40 & 1.50 & 0.04 & 0.08 & 0.08 & 0.21 & -0.04 & 0.10 & 1.00 & & \\
\hline 8 Subsidies & 0.00 & 0.00 & 0.00 & -0.01 & -0.03 & -0.02 & 0.03 & -0.01 & 0.05 & 1.00 & \\
\hline 9 Prop. male & 0.21 & 0.39 & 0.05 & 0.07 & 0.02 & -0.06 & 0.05 & -0.02 & 0.28 & 0.08 & 1.00 \\
\hline 10 Prop. highly educated & 0.04 & 0.17 & -0.09 & -0.08 & 0.02 & 0.02 & -0.03 & 0.04 & 0.18 & -0.01 & 0.22 \\
\hline
\end{tabular}

Notes. Based on full dataset. 


\section{Leverage}

\begin{tabular}{|c|c|c|c|}
\hline & $\begin{array}{c}\text { GEE } \\
\text { Model } 1 \\
\end{array}$ & $\begin{array}{c}\text { GEE } \\
\text { Model } 2 \\
\end{array}$ & $\begin{array}{c}\text { GEE } \\
\text { Model } 3 \\
\end{array}$ \\
\hline SEs & & $\begin{array}{c}-0.078 * * \\
{[0.027]}\end{array}$ & $\begin{array}{c}-0.123 * * * \\
{[0.035]}\end{array}$ \\
\hline SEs $x$ Time & & & $\begin{array}{l}0.011^{*} \\
{[0.006]}\end{array}$ \\
\hline Time & $\begin{array}{l}-0.003 \\
{[0.007]}\end{array}$ & $\begin{array}{l}-0.003 \\
{[0.007]}\end{array}$ & $\begin{array}{l}-0.008 \\
{[0.007]}\end{array}$ \\
\hline Profitability & $\begin{array}{c}-0.101 * * \\
{[0.038]}\end{array}$ & $\begin{array}{c}-0.108 * * \\
{[0.038]}\end{array}$ & $\begin{array}{c}-0.104^{* *} \\
{[0.038]}\end{array}$ \\
\hline Tangibility & $\begin{array}{c}0.173 * * * \\
{[0.042]}\end{array}$ & $\begin{array}{c}0.162 * * * \\
{[0.042]}\end{array}$ & $\begin{array}{c}0.167 * * * \\
{[0.042]}\end{array}$ \\
\hline Growth & $\begin{array}{l}0.025^{*} \\
{[0.011]}\end{array}$ & $\begin{array}{l}0.026^{*} \\
{[0.011]}\end{array}$ & $\begin{array}{l}0.030^{* *} \\
{[0.011]}\end{array}$ \\
\hline Size & $\begin{array}{l}0.018 \sim \\
{[0.009]}\end{array}$ & $\begin{array}{l}0.020^{*} \\
{[0.009]}\end{array}$ & $\begin{array}{l}0.018 \sim \\
{[0.009]}\end{array}$ \\
\hline Subsidies & $\begin{array}{c}-0.047^{* * *} \\
{[0.013]}\end{array}$ & $\begin{array}{c}-0.042 * * * \\
{[0.013]}\end{array}$ & $\begin{array}{c}-0.054 * * * \\
{[0.014]}\end{array}$ \\
\hline Prop. male & $\begin{array}{c}0.027 \\
{[0.025]}\end{array}$ & $\begin{array}{c}0.027 \\
{[0.025]}\end{array}$ & $\begin{array}{c}0.027 \\
{[0.025]}\end{array}$ \\
\hline Prop. highly educated & $\begin{array}{c}0.011 \\
{[0.047]}\end{array}$ & $\begin{array}{c}0.017 \\
{[0.047]}\end{array}$ & $\begin{array}{c}0.014 \\
{[0.047]}\end{array}$ \\
\hline Industry fixed effects & Yes & Yes & Yes \\
\hline Year fixed effects & Yes & Yes & Yes \\
\hline $\begin{array}{l}\text { No. of observations } \\
\text { No. of firms }\end{array}$ & $\begin{array}{l}1,276 \\
240\end{array}$ & $\begin{array}{l}1,276 \\
240\end{array}$ & $\begin{array}{l}1,276 \\
240\end{array}$ \\
\hline Wald chi2 & $144.5^{* * *}$ & $213.3 * * *$ & $198.3 * * *$ \\
\hline
\end{tabular}

Notes. Based on full dataset. Robust standard errors in brackets.

$* * * \mathrm{p}<0.001,{ }^{* *} \mathrm{p}<0.01,{ }^{*} \mathrm{p}<0.05, \sim \mathrm{p}<0.10$ 


\begin{tabular}{|c|c|c|c|c|c|c|}
\hline & \multicolumn{3}{|c|}{ Leverage } & \multicolumn{3}{|c|}{ Leverage } \\
\hline & $\begin{array}{c}\text { GEE } \\
\text { SEs } \\
\text { Model 1 }\end{array}$ & $\begin{array}{c}\text { GEE } \\
\text { CEs } \\
\text { Model } 2\end{array}$ & $\begin{array}{c}\text { Diff. } \\
\text { (p-values) }\end{array}$ & $\begin{array}{c}\text { GEE } \\
\text { SEs } \\
\text { Model } 3\end{array}$ & $\begin{array}{c}\text { GEE } \\
\text { CEs } \\
\text { Model } 4\end{array}$ & $\begin{array}{c}\text { Diff. } \\
\text { (p-values) }\end{array}$ \\
\hline Initial leverage & $\begin{array}{c}0.548^{* * *} \\
{[0.090]}\end{array}$ & $\begin{array}{c}0.600 * * * \\
{[0.069]}\end{array}$ & 0.832 & $\begin{array}{c}0.591 * * * \\
{[0.133]}\end{array}$ & $\begin{array}{c}0.949 * * * \\
{[0.071]}\end{array}$ & 0.010 \\
\hline Initial leverage $\mathrm{x}$ Time & & & & $\begin{array}{c}-0.012 \\
{[0.019]}\end{array}$ & $\begin{array}{c}-0.072 * * * \\
{[0.014]}\end{array}$ & 0.003 \\
\hline Time & $\begin{array}{c}-0.006 \\
{[0.007]}\end{array}$ & $\begin{array}{c}-0.012 \sim \\
{[0.007]}\end{array}$ & 0.257 & $\begin{array}{c}-0.004 \\
{[0.007]}\end{array}$ & $\begin{array}{c}0.006 \\
{[0.007]}\end{array}$ & 0.452 \\
\hline Profitability & $\begin{array}{l}-0.126^{*} \\
{[0.051]}\end{array}$ & $\begin{array}{c}-0.089 \sim \\
{[0.046]}\end{array}$ & 0.998 & $\begin{array}{l}-0.123^{*} \\
{[0.052]}\end{array}$ & $\begin{array}{l}-0.076 \sim \\
{[0.045]}\end{array}$ & 0.766 \\
\hline Tangibility & $\begin{array}{c}0.049 \\
{[0.054]}\end{array}$ & $\begin{array}{l}0.128^{*} \\
{[0.052]}\end{array}$ & 0.786 & $\begin{array}{c}0.049 \\
{[0.053]}\end{array}$ & $\begin{array}{l}0.110^{*} \\
{[0.050]}\end{array}$ & 0.856 \\
\hline Growth & $\begin{array}{c}0.028^{*} \\
{[0.014]}\end{array}$ & $\begin{array}{l}0.052 * \\
{[0.021]}\end{array}$ & 0.232 & $\begin{array}{c}0.029^{*} \\
{[0.014]}\end{array}$ & $\begin{array}{l}0.070^{* *} \\
{[0.022]}\end{array}$ & 0.076 \\
\hline Size & $\begin{array}{c}0.027^{* *} \\
{[0.009]}\end{array}$ & $\begin{array}{c}0.004 \\
{[0.012]}\end{array}$ & 0.533 & $\begin{array}{l}0.026^{* *} \\
{[0.009]}\end{array}$ & $\begin{array}{c}-0.005 \\
{[0.011]}\end{array}$ & 0.391 \\
\hline Subsidies & $\begin{array}{c}-0.044^{* *} \\
{[0.014]}\end{array}$ & $\begin{array}{c}-0.762 \\
{[0.560]}\end{array}$ & 0.823 & $\begin{array}{c}-0.045^{* * *} \\
{[0.014]}\end{array}$ & $\begin{array}{c}-0.715 \\
{[0.554]}\end{array}$ & 0.972 \\
\hline Prop. male & $\begin{array}{c}0.056 \\
{[0.041]}\end{array}$ & $\begin{array}{l}-0.009 \\
{[0.027]}\end{array}$ & 0.069 & $\begin{array}{c}0.055 \\
{[0.041]}\end{array}$ & $\begin{array}{c}0.006 \\
{[0.029]}\end{array}$ & 0.091 \\
\hline Prop. highly educated & $\begin{array}{c}0.049 \\
{[0.061]}\end{array}$ & $\begin{array}{l}-0.035 \\
{[0.023]}\end{array}$ & 0.223 & $\begin{array}{c}0.050 \\
{[0.061]}\end{array}$ & $\begin{array}{l}-0.050^{*} \\
{[0.021]}\end{array}$ & 0.215 \\
\hline Industry fixed effects & Yes & Yes & & Yes & Yes & \\
\hline Year fixed effects & Yes & Yes & & Yes & Yes & \\
\hline No. of observations & 607 & 669 & & 607 & 669 & \\
\hline No. of firms & 120 & 120 & & 120 & 120 & \\
\hline Wald chi2 & $204.5^{* * *}$ & $287.2 * * *$ & & $206.1 * * *$ & $388.5 * * *$ & \\
\hline
\end{tabular}

Notes. Based on full dataset. Robust standard errors in brackets.

${ }^{* * *} \mathrm{p}<0.001,{ }^{* *} \mathrm{p}<0.01,{ }^{*} \mathrm{p}<0.05, \sim \mathrm{p}<0.10$ 
Figure 1: Leverage over time for SEs and CEs

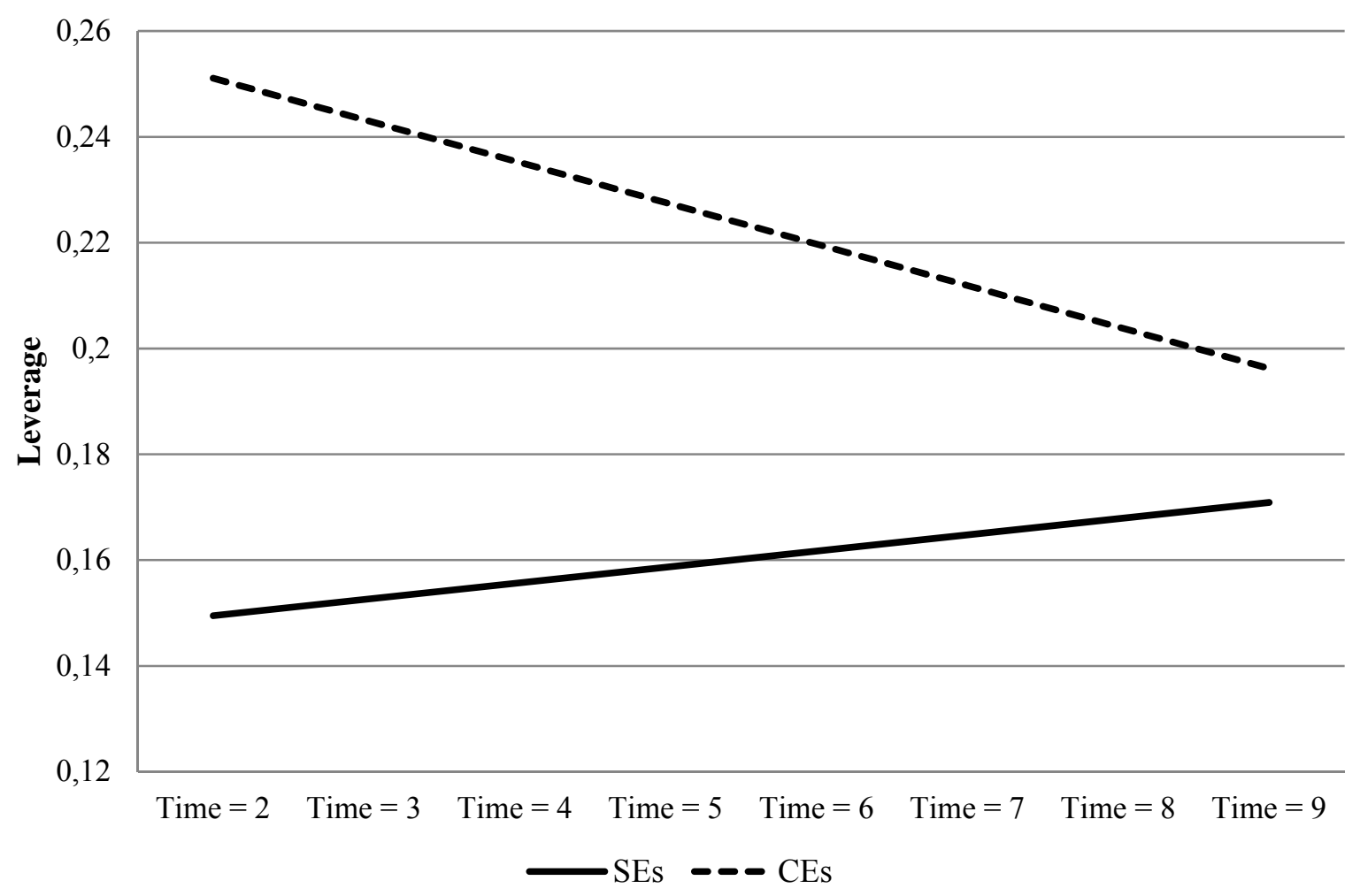

Notes. Mann-Whitney $U$ Tests (unreported) show that the differences in predicted leverage between forprofit social enterprises and commercial enterprises are statistically significant at all time points (with $\mathrm{p}<$ 0.01 for all years, except year 9 with a $\mathrm{p}<0.10$ ). 
Figure 2: Estimated coefficients of initial leverage for SEs and CEs using cross-sectional regressions at different time points

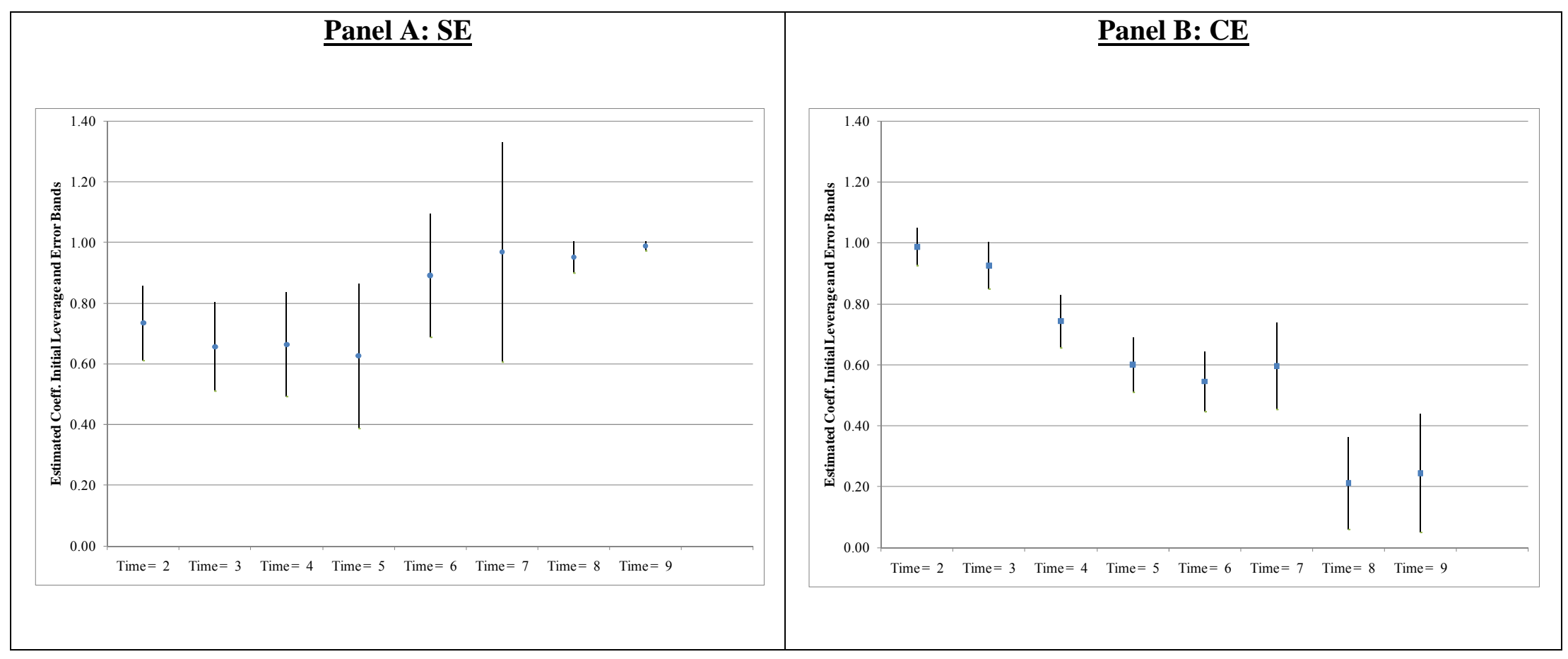

